\title{
Lumbar Intradural Paragangliomas: Report of Two Cases
}

\section{Lomber Intradural Paragangliomalar: İki Olgu Sunumu}

\author{
Mehmet SIMSEK ${ }^{1}$, Mehmet Resid ONEN ${ }^{1}$, Fatima Gursoy ZERENLER², Gozde KIR², Sait NADERI ${ }^{1}$ \\ ${ }_{1}^{1}$ Umraniye Teaching and Research Hospital, Department of Neurosurgery, Istanbul, Turkey \\ ${ }^{2}$ Umraniye Teaching and Research Hospital, Department of Pathology, Istanbul, Turkey
}

Corresponding Author: Mehmet Resid ONEN / E-mail: mresid@gmail.com

\begin{abstract}
Paraganglioma (PG) is a rare tumor of the dispersed neuroendocrine system. PG derives from the embryonic sympathetic and parasympathetic nervous system. Paraganglioma is a neoplasm of the dispersed neuroendocrine system that affects a variety of anatomic sites, mainly the head and neck. It occurs commonly in the carotid body, glomus jugulare, mediastinum and retroperitoneum. Primary spinal paragangliomas are quite rare tumors. They are commonly located in the cauda equina region, and manifest their own clinical and radiological features. In this study, two cases of lumbar intradural paragangliomas are presented. Both of the tumors were totally resected with surgery and there was no evidence of recurrence or metastases during follow-up period. It was concluded that paragangliomas should be taken into consideration during the preoperative workup studies of lumbar intradural tumors.
\end{abstract}

KEYWORDS: Lumbar paragangliomas, Cauda equina, Paraganglioma, Spinal tumor

öz

Nöroendokrin sistemin nadir tümörlerinden biri de paragangliomdur (PG). PG'lar embriyonik sempatik ve parasempatik sinir sisteminden türemiştir. PG'lar başta baş-boyun olmaküzere nöroendokrin sistemin birçok bölgesindegörülebilir. Glomus jugulare, mediasten, retroperitoneal bölge ve karotis en sık görüldüğü yerlerdir. Primer spinal PG'lar ise oldukça nadir görülen tümörlerdir. Bunlar genellikle kauda ekuina bölgesinde bulunan, klinik ve radyolojik bulgular veren patolojilerdir. Bu çalışmada, lomber intradural bölgeye yerleşmiş, iki PG olgusu sunulmuştur. Her iki tümör cerrahi olarak total çıkarılmış olup, takip süreleri boyunca herhangi bir rekürrens veya metastaz bulgusu saptanmamıştır. Çalışmada ameliyat öncesi lomber intradural yerleşimli tümörlerde, tanı ve tedavi aşamasında, dikkate alınacak unsurlar incelenmiştir.

ANAHTAR SÖZCÜKLER: Lomber paragangliomalar, Kauda equina, Paragangliom, Spinal tümör

\section{INTRODUCTION}

Paragangliomas (PGs) are neuroendocrine system tumors affecting many locations, particularly the head and neck. They occur commonly in the carotid body, glomus jugulare, mediastinum and retroperitoneum (10). PG derives from the embryonic sympathetic and parasympathetic nervous system $(13,15,20,28)$. PGs of the central nervous system have been reported in a few case series, particularly in the cauda equina (24) and spinal nerve roots $(13,15)$. PGs were reported for the first time by Miller and Torack in 1970 and called secretory ependymomas (15). In 1972 Lerman et al. reported a similar case and named it paraganglioma (13). Spinal paragangliomas comprise $3-4 \%$ of all spinal tumors, and about 200 cases of cauda equina PG have been reported in the literature $(1,5,29,30)$.

PGs clinically present with pain of axial or radicular origin, and neurological deficits. Since cauda equina and conus medullaris are the common sites for these tumors, they may cause cauda and conus medullaris symptomatology. PGs may rarely cause uncommon symptoms, such as subarachnoid haemorrhage (3), hydrocephalus (22), and hypertension due to overproduction of catecholamines.

These tumors are often mistaken preoperatively for ependymomas or schwannomas (2). Magnetic resonance imaging (MRI) is currently the best modality demonstrating details of cauda equina PGs $(1,2,26,29)$. As in other cauda equina and conus medullaris tumors, surgery is the treatment of choice. Because PGs are WHO grade I neoplasms and the prognosis is excellent when totally resected, total tumor removal should be aimed (24).

The aim of this study is to report two cases of spinal PGs, and to address the clinical, radiological, and pathological aspects.

\section{CASE REPORTS}

\section{Case 1}

A 36-year-old male was admitted to our department. He complained of progressive right-sided leg and back pain for six months. There was no neurological deficit. MRI of the lumbosacral spine showed a well-defined intradural tumor at the level of L2 measuring about $1.7 \mathrm{~cm}$ in size. The tumor 
appeared as isointense with respect to the spinal cord on T1-weighted sequences and hyperintense on T2-weighted images (Figure 1A, B). The tumor appeared isointense in T1weighted, and hyperintense in T2-weighted MRI sequences (Figure 1A, B). The tumor showed diffuse enhancement after contrast medium injection (Figure 1C, D). The patients underwent L2 total laminectomy. The reddish intradural tumor, attached to the nerves, was resected totally. The tumor was resected totally using microtechnique. Postoperative MRI confirmed total excision of the tumor (Figure 3A-D). The patient was neurologically intact on follow-up 8 months after surgery.

\section{Pathological Findings of Case 1}

The tumor was oval shaped, delicately encapsulated, soft, red-brown and measured $1.7 \times 1 \times 2 \mathrm{~cm}$ in size (Figure 2). Histopathological evaluation revealed a well-differentiated tumor composed of Zellballen surrounded by single layer of sustentacular cells and capillary networks. The uniform round cells possed central, round nuclei with finely stippled chromatin and inconspicuous nuclei with eosinophylic, amphohilic or clear cytoplasm (Figure 4A). Tumor cells showed a Synaptophysin, Chromogranin (+) / Glial fibrillary acidic protein (GFAP) (-) immunoprofile (Figure 4B). This immunoprofile was important to exclude ependymoma that was in the differential diagnosis of spinal PG. All there findings supported a diagnosis of PG.

\section{Case 2}

A 40-year-old male case was admitted to our clinic with low back pain since six months. Neurological examination was normal except for bilateral L4 and L5 hypoesthesia. MR imaging showed a $2.5 \mathrm{~cm}$ intradural tumor at the level of the L4 vertebra. Tumor was hyperintense in T1- (Figure 5A) and hypointense in T2-weighted MRI sequences (Figure $5 B$ ), and showed diffuse contrast enhancement (Figure 5C,D). The patient underwent L4 laminectomy, and tumor was removed totally.
The tumor was resected totally using microtechnique. Postoperative MRI confirmed total excision of the tumor (Figure 6A-D). The patient was neurologically intact on followup 6 months after surgery.

\section{Pathological Findings of Case 2}

Grossly the tumor was red-brown, circumscribed, encapsulated $2.5 \times 0.7 \times 1.2 \mathrm{~cm}$ in size. In some areas, tumor resembled papillary ependymoma, particularly because of the perivascular pseudopapillary pattern superficially. In other areas, the tumor was well differentiated, composed of nests (Zellballen), surrounded by a delicate capillary network. The uniform round tumor cells with round nuclei and generally clear cytoplasm were diffusely positive for synaptophysin and chromogranin but not for GFAP (Figure 7A,B). All there findings supported a diagnosis of PG.

\section{DISCUSSION}

Approximately $90 \%$ of PGs arise in the adrenal gland (phaeochromocytoma), and $90 \%$ of extra-adrenal PGs occur in the carotid body and jugular bulb (31). Almost 200 cases of spinal PGs have been reported so far $(1,5,29)$. The majority of these cases were reported to be located in the intradural space. The vast majority of these tumors are intradural, and found within the cauda equina. However, PGs may be found on either side of the dura. Most extradural spinal PGs are metastatic $(11,12,18,19)$, and are located commonly in the thoracic spine. However, there are some primary spinal extradural PG cases $(7,8)$. Both cases reported here were located in the cauda equina. They form almost $1.8 \%$ of all 106 spinal tumors, and $4.6 \%$ of 43 lumbosacral tumors operated at our institution in the last four years.

The severity of the symptoms and findings of these tumors depends on the location and the size of the tumor. Pain and neurological deficit are the main symptoms. However, PGs may rarely cause uncommon problems, such as subarachnoid haemorrhage (3), hydrocephalus (22), and hypertension and

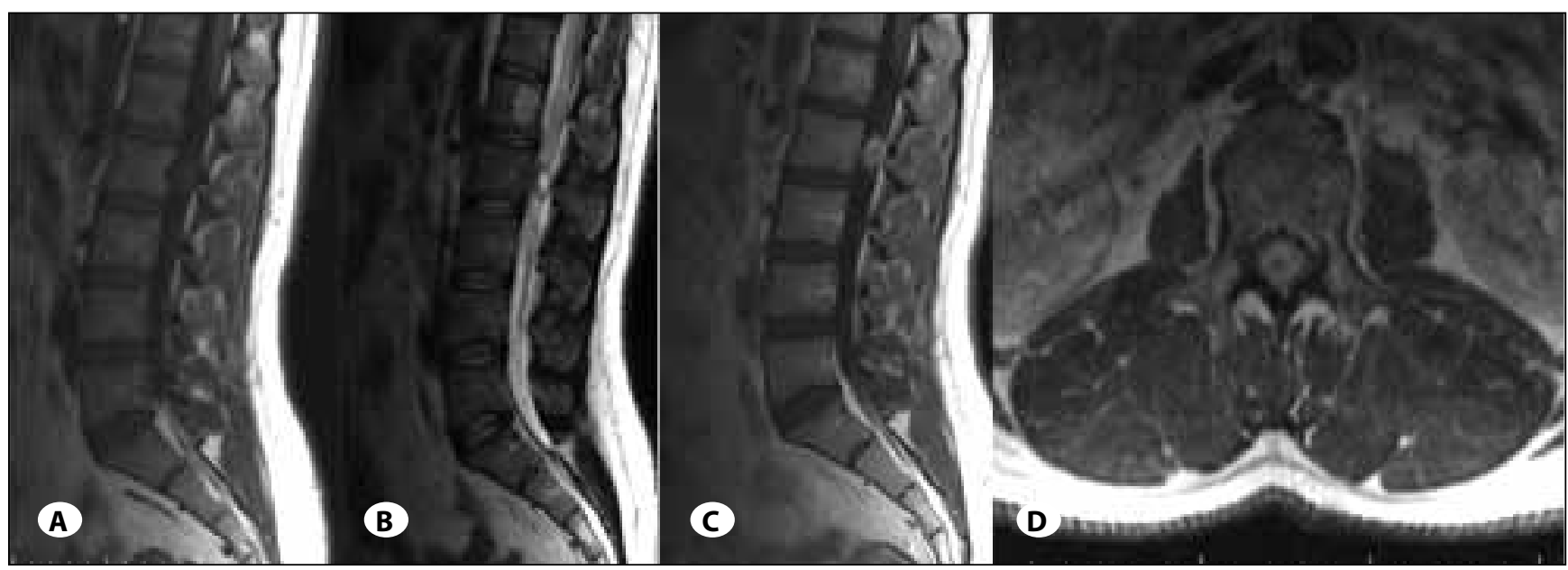

Figure 1: A,B) Sagittal T1 and T2-weighted lumbosacral images showing well-circumscribed tumor at the level of $L 2$. C,D) The tumor showed diffuse contrast enhancement after injection of Gadolinium. 


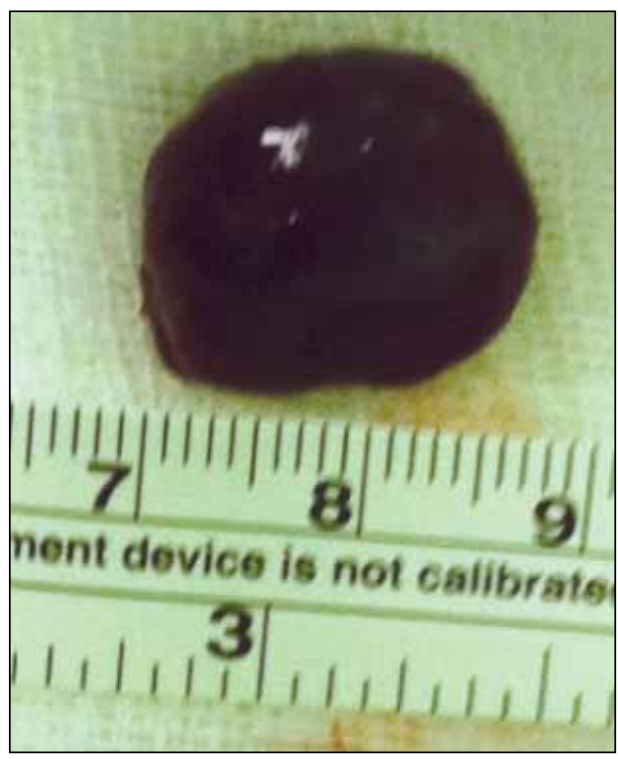

palpitation due to overproduction of catecholamines, which were not evident in our cases.

It is important to consider paraganglioma during preoperative workup of intradural tumors in the cauda equina region. Firstly, paragangliomas may affect endocrine and cardiovascular function via overproduction of catecholamine $(1,15,16,21,29)$. This requires surgeons to be careful to avoid surgical manipulation-related hypertension crisis during surgery. Secondly, paragangliomas are hypervascular tumors (4). However, presurgical radiological diagnosis of PGs is not easy.

MRI may reveal serpentine and congested vessels and a hypointense rim ("cap sign") on T2-weighted images. Cauda equina PGs have no specific MR features. They are seen as Figure 2: $\quad$ hypo- or isointense tumors on T1- and hyperintense on T2The appearance of tumor of the case 1. weighted MR images, showing diffuse contrast enhancement. Herman et al. (6) described MR characteristics of spinal PGs and reported that MRI fails in distinguishing of PGs from other tumors. This is because ependymomas have similar MRI findings to PGs.

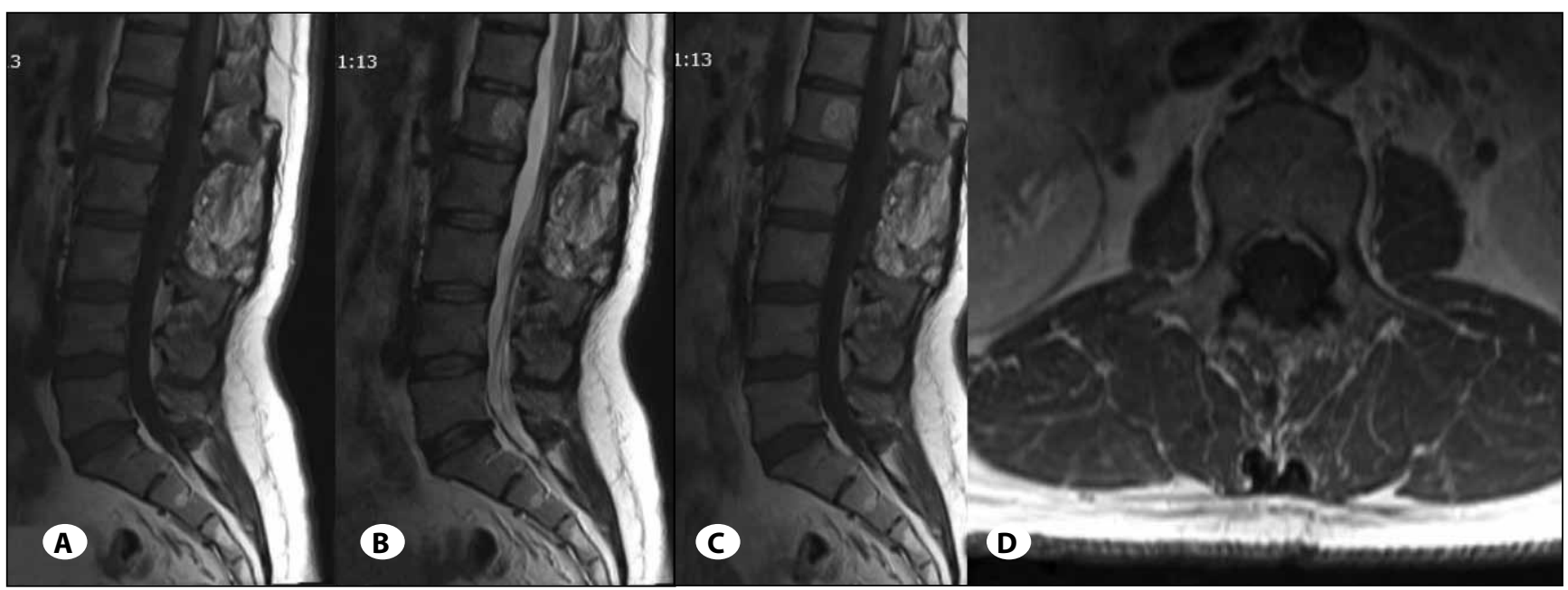

Figure 3: Postoperative precontrast T1 and T2 sagittal images (A, B), and post-contrast sagittal and axial images (C, D) confirming total resection of the tumor.

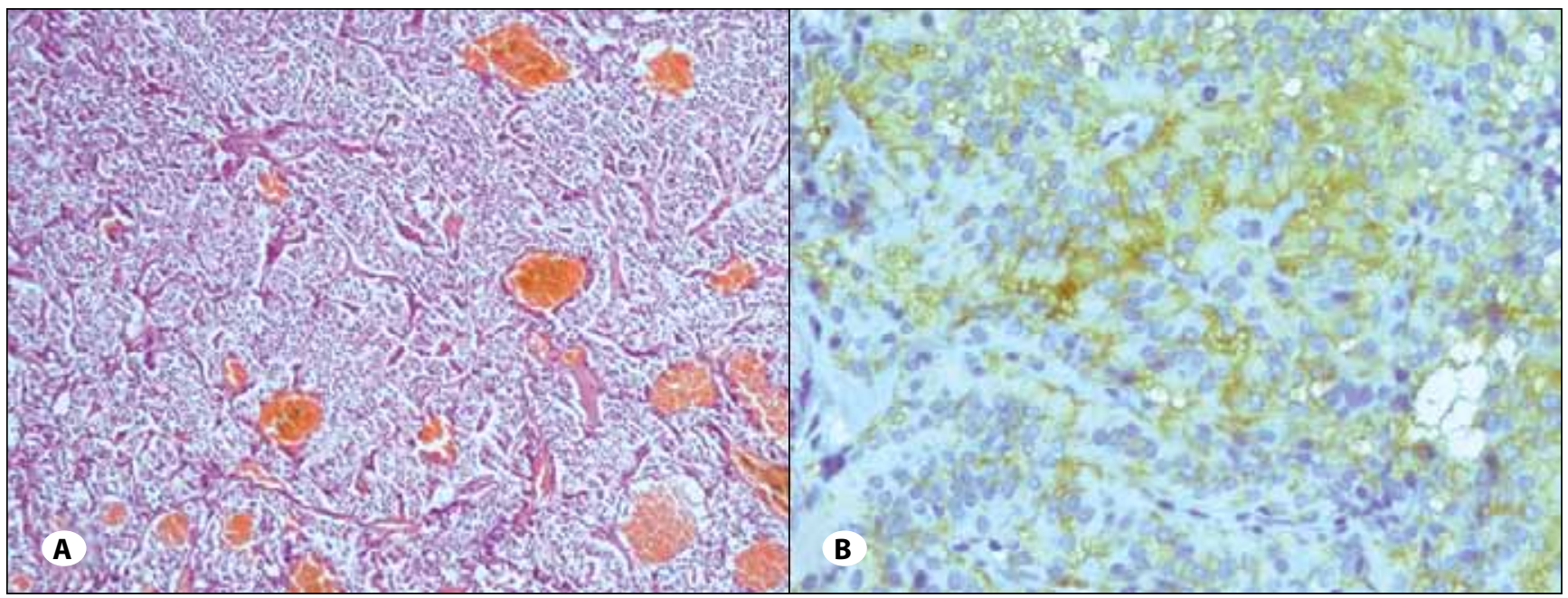

Figure 4: Histological features of case 1. A) Typical Zellballen architecture H\&E (x10). B) Diffuse staining for Synaptophysin (x40). 


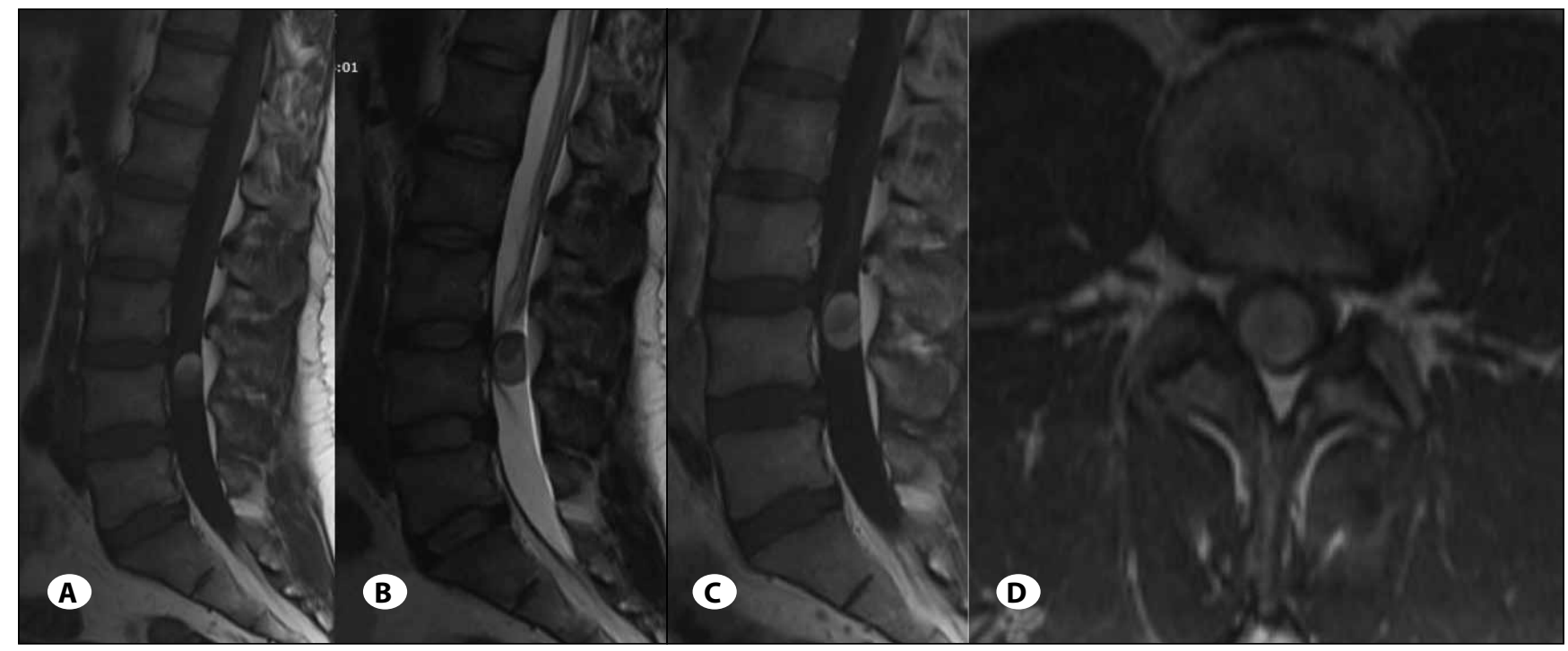

Figure 5: A,B) Sagittal T1 and T2-weighted lumbosacral images showing well-circumscribed tumor at the level of $L 3-4$. C,D) The tumor showed contrast enhancement after injection of Gadolinium.

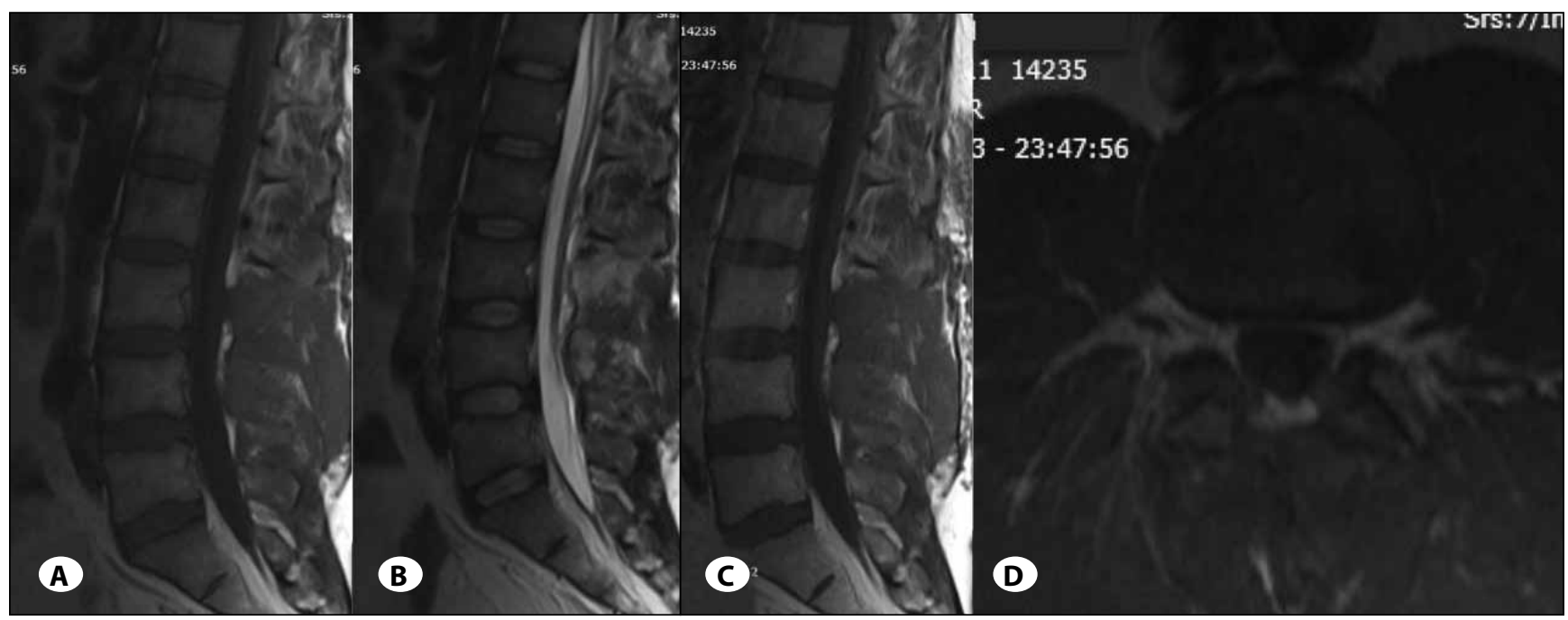

Figure 6: A,B) Postoperative pre T1 and T2 sagittal images, and C,D) post-contrast sagittal and axial images confirming total resection of the tumor.

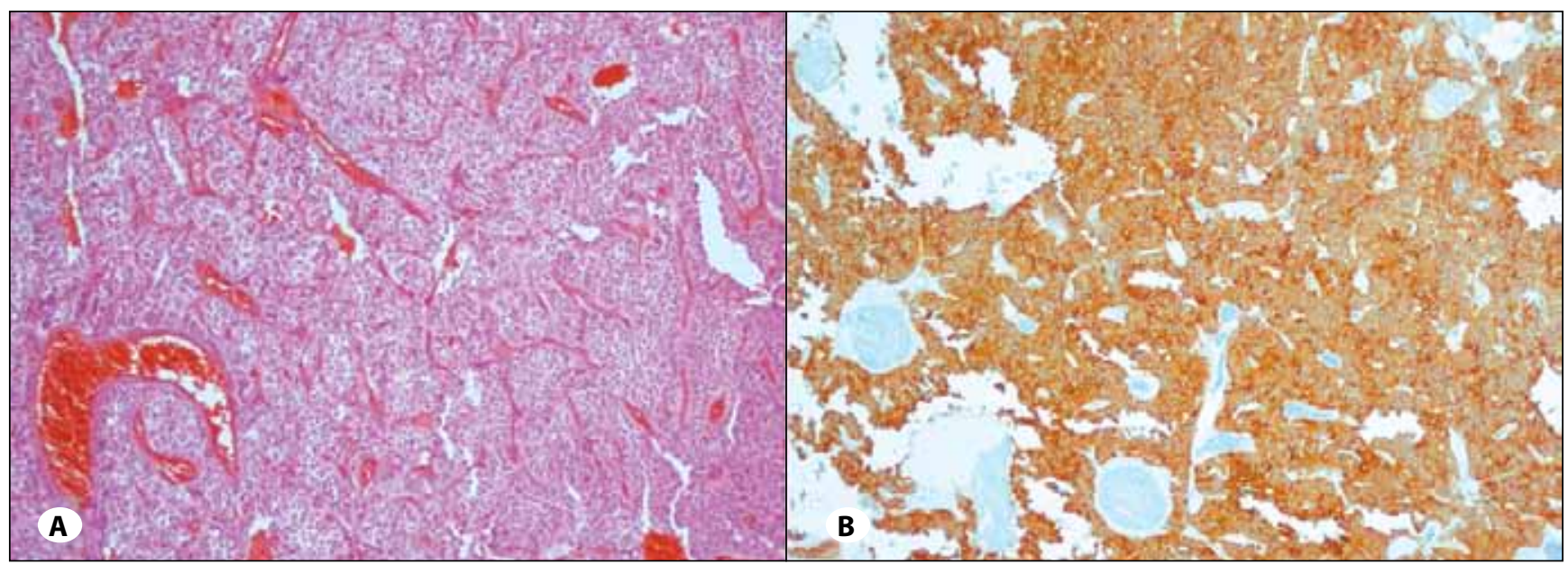

Figure 7: Histological features of Case 2. A) Typical Zellballen architecture H\&E (x10). B) Diffuse staining for Synaptophysin (x10). 
It is of note that preoperative knowledge regarding the vascularity of these tumors, particularly in cases containing serpentine and congested vessels, is important. A careful evaluation of preoperative MRI is essential to differentiate arteriovenous malformations and hypervascular tumors such as paraganglioma, haemangioma or haemangioblastoma (4). The hypervascular nature of tumors may also require preoperative angiography to exclude AVM and to see vascular architecture of the tumor. Kwan et al. reported preoperative tumor embolization to reduce intraoperative bleeding (9).

A hypointense capsule on T2W images, proton density and gradient echo sequences may also be seen due to hemosiderin or ferritin from haemorrhage. This may also suggest PG in the preoperative stage.

Unfortunately we misdiagnosed PGs as ependymoma in our cases and therefore we did not use any other blood or radiological investigation during our preoperative workup. Nevertheless, the tumors were resected totally in both cases.

PGs are well-differentiated tumors composed of Zellballen containing eosinophilic and granular cytoplasm. Histopathological similarities between PGs and ependymomas may causes diagnostic confusion (14)

Immunohistochemistry studies show reactivity for markers of neural differentiation, including synaptophysin, neuron specific enolase, and chromogranin with lack of reactivity for GFAP in most cases. This is a helpful feature for the differential diagnosis of ependymoma, meningioma and schwannoma (23). Both pathological features and immunohistochemical aspects of our both cases supported a diagnosis of PG.

The recommended treatment for spinal PG is total resection. Surgery commonly reveals a well-circumscribed, ovoid to cylindrical intradural, extramedullary tumor, with a maximum dimension of a few centimeters. Complete surgical resection is possible in most cases. When total tumor resection is not possible, radiation treatment is recommended $(8,27)$. Total removal of the entire tumor was achieved in our both cases and no radiation therapy was performed.

In conclusion, cauda equina paragangliomas are rare and benign tumors. Their functional and vascular aspects should be taken into consideration before and during surgery. This requires careful preoperative clinical and radiological evaluation. Optimal treatment includes surgical resection when feasible. In case of subtotal tumor removal, radiation and chemotherapy are other treatment modalities.

\section{REFERENCES}

1. Aghakhani N, George B, Parker F: Paraganglioma of the cauda equina region-report of two cases and review of the literature. Acta Neurochir (Wien) 141: 81-87, 1999

2. Araki $Y$, Ishida $T$, Ootani $M$, Yamamoto $H$, Yamamoto $T$, Tsukaguchi I, Nakamura H: MRI of paraganglioma of the cauda equina. Neuroradiology 35: 232-233, 1993
3. Ashkenazi E, Onesti ST, Kader A, Liena JF: Pararganglioma of the filum teminale: Case report and literature review. J Spinal Disord 11: 540-542, 1998

4. Demircivi F, Aydın M, Bezircioglu H, Oran I: Paraganglioma of the cauda equina: A highly vascular tumour, Journal of Clinical Neuroscience 17: 1445-1447, 2010

5. Gelabert-Gonzalez M: Paragangliomas of the lumbar region. Report of two cases and review of the literature. J Neurosurg Spine 2: 354-365, 2005

6. Herman M, Pozzi-Mucelli RS, Skrap M: Paraganglioma of the cauda equina: Case report and review of the MRI features. Acta Univ Palacki Olomuc Fac Med 141: 27-30, 1998

7. Houten JK, Babu RP, Miller DC: Thoracic paraganglioma presenting with spinal cord compression and metastases. J Spinal Disord Tech 15: 319-323, 2002

8. Jindel R, Gupta AK, Mahapatra AK, Bal CS, Singhal RM: Extradural paraganglioma with multiple skeletal metastases. Br J Radiol 65: 938-940, 1992

9. Kwan RB, Erasmus AM, Hunn AW, Dubey A, Waites P, Jessup PJ, Burgess JR, Beasley A: Pre-operative embolisation of metastatic paraganglioma of the thoracic spine. Journal of Clinical Neuroscience 17: 394-396, 2010

10. Lack EE: Paragangliomas. In: Mills SE (ed), Sternberg's Diagnostic Surgical Pathology. Philadelphia: Lippincott Williams \& Wilkins, 2004:669-696

11. Lau D, Marca F, Piragua SC, Park P: Metastatic paraganglioma of the spine: Case report and review of the literature. Clinical Neurol Neurosurg 11: 1571-1574, 2013

12. Lazaro B, Klemz M, Flores MS, Landeiro JA: Malignant paraganglioma with vertebral metastasis: Case report. Arq Neuropsiquiatr 61: 463-647, 2003

13. Lerman RI, Kaplan ES, Daman L: Ganglioneuromaparaganglioma of the intradural filum terminale. Case report. J Neurosurg 36: 652-658, 1972

14. Midi A, Yener AN, Sav A, Cubuk R: Cauda equina paraganglioma with ependymoma- like histology: A case report. Turk Neurosurg 22: 353-359, 2012

15. Miller CA, Torack RM: Secretory ependymoma of the filum terminale. Acta Neuropathol 15: 240-250, 1970

16. Miliaras GC, Kyritisis AP, Polyzoidis KS: Cauda equina paraganglioma: A review. J Neuro-Oncol 65: 177-190, 2003

17. Moran CA, Rush W, Mena $\mathrm{H}$ : Primary spinal paragangliomas: A clinicopathological and immunohistochemical study of 30 cases. Histopathology 2: 167-173, 1997

18. Mori S, Okura T, Kitami Y, Takata Y, Nakamura M, Watanabe S, Iwata T, Hiwada K: A case of metastatic extra-adrenal pheochromocytoma 12 years after surgery. Hypertens Res 25: 141-144, 2002

19. North CA, Zinreich ES, Christensen WN, North RB: Multiple spinal metastases from paraganglioma. Cancer 66:22242228, 1990

20. Pacak K, Linehan WM, Eisenhofer G, Walther MM, Goldstein DS: Recent advances in genetics, diagnosis, localization, and treatment of pheochromocytoma. Ann Intern Med 134: 315-329, 2001 
21. Pigott TJD, Lowe JS, Morrell K, Kerslake RW: Paraganglioma of the cauda equina: Report of three cases. J Neurosurg 73: 455-458, 1990

22. Rhee HY, Jo DJ, Lee JH, Kim SH: Paraganglioma of the filum terminale presenting with normal pressure Hydrocephalus. Clin Neurol Neurosurg 112: 578-581, 2010

23. Rickerts $\mathrm{CH}$, Probst-Cousin S, Schumacher HW, Gullotta F: Paraganglioma of the cauda equina. Pathologe 18: 484-487, 1997

24. Scheithauer BW, Brandner S, Soffer D: Spinal paraganglioma. In: Louis DN, Ohgaki H, Wiestler OD, Cavenee WK (eds), WHO Classification of Tumours of the Central Nervous System. Lyon: IARC, 2007:117-119

25. Sonneland PR, Scheithauer BW, LeChago J, Crawford BG, Onofrio BM: Paraganglioma of the cauda equina region. Clinicopathological study of 31 cases with special reference to immunocytology and ultrastructure. Cancer 8: 1720-1735, 1986
26. Taira H, Takasita M, Yoshida S, Takita C, Tsumura H, Torisu T: MR appearance of paraganglioma of the cauda equina. Case reports. Acta Radiol 41: 27-30, 2000

27. U-King-Im JM, Carroll TA, Morris K: Vertebral metastatic chemodectoma: Imaging and therapeutic octreotide. Case report. J Neurosurg Spine 97: 106-109, 2002

28. Walsh JC, O'Brien DF, Kumar R, Rawluk D: Paraganglioma of the cauda equina: $A$ case report and literature review. Surgeon 3: 113-116, 2005

29. Yang SY, Jin YJ, Park SH, Jahng TA, Kim HJ, Chung CK: Paragangliomas in the cauda equina region: Clinicopathoradiologic findings in four cases. J Neurooncol 72: 49-55, 2005

30. Zileli M, Kalaycı M, Basdemir G: Paraganglioma of the thoracic spine. J Clin Neurosci 15: 823-827, 2008 